\title{
PENGEMBANGAN MODUL STATISTIK PENDIDIKAN BERBASIS CTL UNTUK MENINGKATKAN KOMPETENSI MAHASISWA UNIVERSITAS RIAU KEPULAUAN BATAM
}

\author{
Yudhi Hanggara, Fitrah Amelia \\ Program Studi Pendidikan Matematika, Fakultas Keguruan dan Ilmu Pendidikan, \\ Universitas Riau Kepulauan, Batam, Kepulauan Riau \\ e-mail: yudhihanggara@gmail.com
}

\begin{abstract}
Abstrak. Statistik Pendidikan merupakan mata kuliah wajib yang harus ditempuh oleh seluruh mahasiswa prodi pendidikan matematika semester VI. Berdasarkan observasi ditemukan bahwa hasil belajar statistik pendidikan mahasiswa masih tergolong rendah. Tujuan penelitian ini adalah untuk menghasilkan bahan ajar berupa modul statistik pendidikan yang valid, praktis, dan efektif untuk meningkatkan kompetensi mahasiswa program studi pendidikan matematika FKIP Unrika Batam pada mata kuliah Statistik pendidikan. Selain itu, penelitian ini bertujuan untuk memberikan tambahan bahan ajar berupa modul statistik pendidikan berbasis CTL yang sesuai dengan karakteristik mahasiswa sehingga dapat memudahkan mahasiswa dalam mempelajari statistik pendidikan. Rancangan penelitian berupa penelitian pengembangan dengan menggunakan model pengembangan 4D atau Four-D (Define, Design, Development, Dissemination). Instrumen yang digunakan dalam penelitian ini adalah angket validasi modul berdasarkan BSNP, angket respon mahasiswa dan tes hasil belajar. Berdasarkan hasil analisis data dapat disimpulkan bahan ajar berupa modul statistik pendidikan berbasis CTL yang dihasilkan telah valid, praktis dan efektif dengan tingkat kevalidan sebesar $85,71 \%$ dengan kategori sangat baik, tingkat kepraktisan sebesar 81,73\% dengan kategori baik dan persentase ketuntasan secara klasikal sebesar 72,73\% dalam kategori baik sehingga dapat disimpulkan bahwa modul yang dikembangkan efektif.
\end{abstract}

Kata Kunci: Modul, Statistik Pendidikan, CTL.

\begin{abstract}
Educational Statistiks is a compulsory subject that must be taken by all students of the sixth semester mathematics education study program. Based on observations found that the learning outcomes of student education statistiks are still relatively low. The purpose of this study is to produce teaching materials in the form of valid, practical, and effective education statistiks module to improve the competency of students of mathematics education program FKIP Unrika Batam in the course of Education Statistiks. In addition, this study aims to provide additional teaching materials in the form of CTL-based education statistiks module in accordance with the characteristics of students so as to facilitate students in studying education statistiks. The research design is development research using 4D or Four-D development model (Define, Design, Development, Dissemination). The instruments used in this study were module validation questionnaires based on BSNP, student response questionnaires and learning outcome testsBased on the results of data analysis can be concluded the teaching materials in the form of CTL-based educational statistiks module that has been produced has valid, practical and effective with the level of $85.71 \%$ validity with the category very good, the practical level of $81.73 \%$ with good category and percentage mastery in kalsikal $72.73 \%$ in both categories so it can be concluded that the module developed effectively.
\end{abstract}

Keyword: Module, education statistiks, CTL.

\section{Pendahuluan}

Statistik pendidikan merupakan bagian dari matematika yang memainkan peranan penting baik dalam kehidupan maupun dalam pembuatan tugas akhir mahasiwa. Mata kuliah statistik pendidikan diajarkan disemua jurusan yang ada di Universitas Riau Kepulauan. Dalam Program studi pendidikan matematika, statistik pendidikan diberikan pada semester 
VI. Mata kuliah tersebut merupakan mata kuliah wajib yang harus ditempuh oleh seluruh mahasiswa. Tujuan pemberian mata kuliah statistik pendidikan berdasarkan silabus yang digunakan adalah agar mahasiswa mempunyai pengetahuan dan pemahaman tentang konsep dasar statistika yang berkaitan pengujian atau analisis data statistik yang banyak digunakan dalam praktek penyusunan tugas akhir skripsi dan penggunaan software berbasis statistik untuk penelitian serta penerapan dalam dunia kerja baik di bidang matematika maupun bidang lainnya yang berkaitan.

Berdasarkan pengalaman peneliti dalam mengampu mata kuliah statistik pendidikan, masih terdapat mahasiswa yang mengalami kesulitan dalam mengikuti perkuliahan. Setelah dilakukan wawancara informal dengan mahasiswa, diperoleh informasi bahwa kesulitan mahasiswa adalah pada banyaknya rumus yang ada, kemudian dalam analisis suatu kasus mahasiswa kesulitan dalam merumuskan hipotesis dan statistik ujinya. Hal ini diperkuat dengan angket analisis kebutuhan yang menyatakan bahwa mahasiswa merasa kesulitan dalam mempelajari statistik karena terlalu banyak rumus yang digunakan dengan persentase sebesar $83,33 \%$. Mahasiswa juga mengatakan sangat membutuhkan bahan ajar yang mudah untuk dipelajari, karena bahan ajar yang digunakan saat ini yaitu berupa buku penyajian konsepnya kurang runtut, contoh-contoh soal banyak yang sudah tidak relevan dengan kehidupan saat ini, dan langkah-langkah penyelesaian yang diberikan tidak detail sehingga membuat mahasiswa bingung terutama jika diminta untuk belajar mandiri. Hal ini dimungkinkan karena buku yang digunakan merupakan cetakan lama sehingga bahasanya kaku, dan di Kota Batam memang cukup sulit untuk mendapatkan buku-buku referensi perkuliahan yang relevan dan berkualitas.

Kondisi tersebut menyebabkan mahasiswa hanya bergantung untuk mencatat materi maupun latihan soal yang disampaikan dosen selama perkuliahan. Hasil wawancara lanjutan dengan mahasiswa, mereka sangat berharap untuk dapat memiliki suatu bahan ajar yang mudah untuk dipelajari, yang dapat membantu mereka dalam memahami materi yang disusun secara sistematis dan menarik sehingga mereka bisa belajar baik di kelas maupun mandiri.

Oleh karena itu perlu dikembangkan bahan ajar yang dapat membantu mahasiswa dalam memahami materi dan dapat membantu mahasiswa memperoleh alternatif buku pegangan selain buku teks yang ada saat ini. Bahan ajar tersebut dapat berupa modul yang dapat didesain secara menarik dengan bahasa yang tidak kaku. Berdasarkan angket kebutuhan yang diberikan kepada mahasiswa, mereka menginginkan adanya suatu bahan ajar yang mengaitkan materi dengan kehidupan sehari-hari. Oleh karena itu modul yang akan dikembangkan didesain dengan menggunakan pendekatan CTL. Untuk mempelajari statisitik pendidikan yang penerapannya banyak digunakan dalam kehidupan tentu akan sangat cocok jika menggunakan prinsip-prinsip pendekatan Kontekstual (CTL). Pendekatan pembelajaran kontekstual adalah sebuah sistem yang merangsang otak untuk menyusun pola-pola yang menghubungkan muatan akademis dengan konteks dalam kehidupan sehari-hari sehingga menghasilkan suatu makna. Dengan demikian diharapkan materi-materi yang disajikan dapat mudah dipahami oleh mahasiswa.

Dalam hal ini, dimana mahasiswa Unrika yang sebagian sudah bekerja tentunya akan lebih mudah memahami materi statistik pendidikan apabila dalam penyajian konsep dan contohnya menggunakan masalah-masalah yang sering mereka alami dalam dunia kerja maupun dalam kaitannya dengan penyusunan tugas akhir skripsi mereka kelak. Hal ini sesuai 
dengan pernyataan Régnier \& Kuznetsova (2014) bahwa situasi mendasar dalam pengajaran statistik harus sesuai dengan status disiplin (bidang ilmu) dan kategori siswa. Artinya tingkatan siswa yang diajar apakah berada pada level sekolah dasar, menengah atau universitas. Sehingga harus disajikan permasalahan-permasalahan yang relevan dengan kondisi yang sering dialami siswa agar proses belajar menjadi lebih mudah dipahami dan bermanfaat dalam kehidupan siswa. Selain itu berdasarkan Laporan Guidelines for Assessment and Instruction in Statistiks Education (GAISE) pada tahun 2000 dalam (Kahle, 2012) merekomendasikan 6 hal terkait pembelajaran statistika, dua diantaranya bahwa pembelajaran statistika harus memenuhi $(i)$ stress conceptual understanding, rather than mere knowledge of procedure; (ii) foster active learning in the classroom. Dalam laporan ini pembelajaran statistik perlu ditekankan pada pemahaman konsep bukan hanya sekedar pengetahuan tentang prosedur. Selain itu dalam laporan ini juga diperlukan pembelajaran aktif dalam mengajarkan konsep statistik di kelas.

Berdasarkan uraian di atas, maka diperlukan adanya bahan ajar yang bisa menjadi alternatif buku pegangan mahasiswa selain buku cetak. Bahan ajar yang dikembangkan dapat berupa modul. Nasution (2005) mangatakan bahwa modul adalah suatu unit yang lengkap yang berdiri sendiri dan terdiri atas suatu rangkaian kegiatan belajar yang disusun untuk membantu siswa mencapai sejumlah tujuan yang dirumuskan dengan khusus dan jelas. Selain itu Anwar (2010) juga mengemukakan bahwa modul pembelajaran adalah bahan ajar yang disusun secara sistematis dan menarik yang mencakup isi materi, metode dan evaluasi yang dapat digunakan secara mandiri untuk mencapai kompetensi yang diharapkan. Berdasarkan pengertian modul tersebut dapat didefinisikan bahwa modul adalah bahan ajar yang disusun secara sistematis untuk memudahkan siswa belajar secara mandiri sesuai dengan tujuan yang ingin dicapai. Modul yang dikembangkan haruslah menarik dan mudah dipahami oleh mahasiswa.

Berdasarkan penelitian Shahidayanti et al (2014) dan Nasiroh (2014) disimpulkan bahwa hasil penelitian pengembangan modul dengan pendekatan kontekstual dapat meningkatkan hasil belajar siswa. Oleh karena itu, peneliti mencoba untuk mengembangkan modul statistik pendidikan berbasil kontekstual (CTL). Modul Statistik pendidikan berbasis CTL ini berbeda dengan modul-modul yang lain karena dalam modul ini disajikan masalah nyata dalam kehidupan sehari-hari siswa sehingga diharapkan dapat membantu mahasiswa memahami materi statistik dengan mudah.

\section{Metode Penelitian}

Penelitian ini merupakan penelitian pengembangan (research and development). Model pengembangan yang digunakan dalam penelitian ini merujuk pada teori pengembangan dari Thiagarajan yaitu model pengembangan 4D (define, design, development, and dissemination). Model pengembangan ini secara sistematis pada gambar 1: 


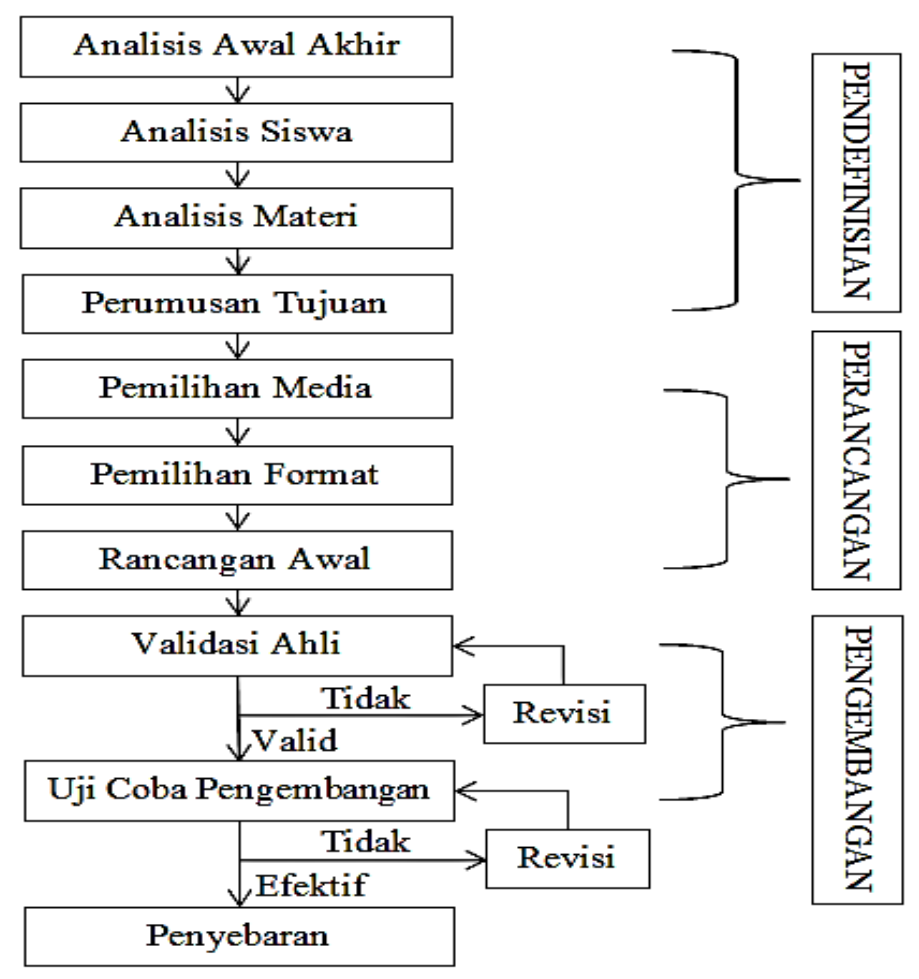

Gambar 1. Tahap Pengembangan modul

Uji coba dilakukan pada semester VI kelas B dengan jumlah subjek uji coba sebanyak 22 mahasiswa. Data penelitian ini dikumpulkan melalui lembar validasi modul untuk mengukur kevalidan modul, tes hasil belajar siswa untuk mengukur keefektifan modul, dan angket respon siswa untuk mengukur kepraktisan modul.

Data yang diperoleh dalam penelitian ini akan dianalisis secara deskriptif kualitatif. Dimana data yang diperoleh dari data validitas, keefektifan dan kepraktisan dari modul dianalisis dengan cara kuantitatif kemudian digunakan dengan teknik deskriptif untuk menarik kesimpulan secara kualitatif.

\section{Hasil Penelitian Dan Pembahasan \\ Hasil Penelitian}

Berdasarkan model pengembangan 4D, langkah-langkah pengembangan modul statistik pendidikan berbasis CTL dilakukan melalui tahapan berikut:

\section{Tahap Pendefinisian (Define)}

Tahap awal yang dilakukan dalam pengembangan modul Statistik Pendidikan ini adalah tahap pendefinisian. Tahapan ini merupakan kegiatan analisis kebutuhan tentang jenis produk apa yang dibutuhkan oleh mahasiswa. Dalam tahap pendefinisian menurut Thiagarajan (1974) sebagai berikut:

\section{a. Analisis Ujung Depan}

Analisis ujung depan bertujuan untuk memunculkan dan menetapkan masalah dasar yang dihadapi dalam pembelajaran. Berdasarkan angket yang disebarkan kepada mahasiswa, 15 mahasiswa $(71,42 \%)$ dari 21 mahasiswa yang diberi angket mengatakan bahwa mereka mengalami kesulitan dalam mempelajari statistik. Mereka mengalami 
kesulitan belajar statistik dikarenakan rumus dalam statistik terlalu banyak dan mereka juga tidak tahu tentang kapan rumus yang ada dalam statistik itu dapat digunakan. Berdasarkan butir ke 10 dalam angket semua mahasiswa membutuhkan suatu bahan ajar untuk dikembangkan dalam mempelajari Statistik. Berdasarkan hasil angket $(80,95 \%)$ 17 mahasiswa menginginkan bahan ajar yang dikembangkan adalah berupa modul dan sisanya (19,05\%) 4 mahasiswa menginginkan buku cetak. Selain itu beberapa mahasiswa juga mengatakan bahwa mereka memilih modul sebagai sumber belajarnya adalah karena dalam modul bahasanya lebih mudah dipahami dan disertai dengan contoh sehingga dapat memudahkan mereka untuk belajar. Sehingga peneliti dapat mendefinisikan bahan ajar yang akan dikembangkan adalah berupa modul.

\section{b. Analisis Karakteristik Mahasiswa}

Analisis karakteristik Mahasiswa bertujuan untuk mengetahui karakteristik mahasiswa yang sesuai dengan desain pengembangan perangkat pembelajaran. Berdasarkan observasi peneliti sebagian besar mahasiswa adalah pekerja dan mereka kesulitan untuk mempelajari materi melalui buku cetak saja. Selain itu dari segi sosial ekonomi mahasiswa program studi pendidikan matematika tergolong pada ekonomi menegah kebawah. Berdasarkan wawancara informal mereka mengatakan bahwa untuk membiayai kuliahnya mereka harus bekerja karena orang tua mereka tidak mampu untuk membiayainya, sehingga mahasiswa tersebut tidak mampu untuk membeli banyak buku referensi. Selanjutnya berdasarkan angket yang disebarkan mereka mengatakan buku paket yang mereka miliki sekarang kurang relevan untuk dipelajari. Terkadang antara satu buku dengan buku lain terdapat simbol-simbol yang berbeda sehingga mereka kesulitan mempelajari materi secara mandiri. Mahasiswa juga mengatakan mereka dapat lebih mudah mempelajari materi jika bahan ajar yang dikembangkan sesuai dengan kehidupan sehari-hari mereka (kontekstual).

\section{c. Analisis Materi}

Analisis materi ini mencakup analisis tugas (task analysis) dan analisis konsep (concept analysis) yang bertujuan untuk menentukan isi dalam satuan pembelajaran. Peneliti melakukan (1) analisis silabus dan RPS, (2) analisis sumber belajar, yakni mengumpulkan dan mengidentifikasi sumber-sumber mana yang mendukung penyusunan bahan ajar. Bedasarkan silabus dan RPS materi yang akan dikembangkan dalam mata kuliah statistik pendidikan meliputi: 1) Konsep Dasar Statistik, 2) Hipotesis Penelitian, 3) Uji Prasyarat Analisis Statistik, 4) Pengujian Hipotesis Deskriptif, 5) Analisis Komparatif, 6) Analisis Korelasi dan 7) Analisis Regresi. Berdasarkan analisis diketahui bahwa kompetensi yang harus dikuasai mahasiswa cukup banyak dan untuk memahami suatu materi diperlukan pemahaman materi sebelumnya. Sedangkan analisis pada sumber-sumber belajar (referensi) bertujuan untuk melihat isi buku secara mendalam yang meliputi cara penyajian, dan soal-soal latihan. Berdasarkan analisis diperoleh bahwa dalam penyajian buku-buku statistik pendidikan yang ada belum mampu membuat mahasiswa memahami materi secara mandiri. Selain itu juga contohcontoh yang ada dalam buku tersebut masih kurang mengaitkan dengan kehidupan sehari-hari mereka. 


\section{d. Perumusan Tujuan Pembelajaran}

Perumusan tujuan pembelajaran berguna untuk merangkum hasil dari analisis materi untuk menentukan perilaku objek penelitian. Adapun tujuan pembelajaran yang ingin dicapai dalam mempelajari modul statistik pendidikan ini adalah:

1. Mahasiswa dapat memahami konsep dasar statistik dan statistika, macam-macam data, populasi dan sampel, serta teknik pengambilan sampel penelitian.

2. Mahasiswa dapat memahami tentang hipotesis penelitian dan dapat memberikan contoh masing-masing jenis hipotesis penelitian.

3. Mahasiswa dapat memahami tentang jenis-jenis uji prasyarat analisis statistik yang meliputi: Uji Normalitas, Uji Homogenitas dan Uji Linieritas secara manual maupun dengan aplikasi SPSS.

4. Mahasiswa dapat memahami tentang pengujian hipotesis deskriptif secara manual dan dengan aplikasi SPSS.

5. Mahasiswa dapat memahami tentang analisis komparatif yang meliputi: uji-t dua sampel independen, uji-t dua sampel berpasangan, analisis variansi satu jalur, analisis variansi dua jalur baik secara manual maupun dengan menggunakan aplikasi spss.

6. Mahasiswa dapat memahami tentang analisis korelasi sederhana dan korelasi ganda secara manual dan dengan aplikasi SPSS.

7. Mahasiswa dapat memahami tentang analisis regresi linier sederhana dan regresi linier ganda secara manual dan dengan aplikasi SPSS.

\section{Tahap Design}

Hasil dari tahap define (pendefinisian) diguakan sebagai acuan untuk merancang bahan ajar apa yang paling tepat dikembangkan pada mata kuliah statistik pendidikan. Pada tahap design ini tindakan yang dilakukanpeneliti adalahsebagai berikut:

a. Pemilihan media

Berdasarkan tahap define yang sudah dilaksanakan maka bahan ajar yang dikembangkan dalam mata kuliah statistik pendidikan ini adalah berupa modul statistik pendidikan berbasis kontekstual yang terdiri dari 7 pokok bahasan. Hal ini sesuai dengan hasil analisis kebutuhan mahasiswa terhadap bahan ajar yang bisa dipelajari secara mandiri dan dilengkapi dengan contoh-contoh soal yang mengaitkan dengan kehidupan sehari-hari.

b. Pemilihan format

Pada tahap ini peneliti memilih format modul yang terdiri dari: (1) Pendahuluan; (2) isi materi bahan, uraian dan contoh; (3) soal-soal latihan.

c. Rancangan awal

Dalam tahap ini peneliti membuat produk awal (prototipe) atau rancangan produk awal. Adapun rancangan produk awal modul yang akan dikembangkan meliputi (1) Cover; (2) Kata Pengantar; (3) Daftar Isi; (4) Pertunjuk Penggunaan Modul; (5) Pokok Bahasan yang terdiri dari 7 Bab; (6) Daftar Pustaka.

\section{Tahap Development}

Tahap pengembangan berisi kegiatan membuat rancangan menjadi produk dan menguji validitas produk kepada ahli materi dan ahli media. Langkah yang dilakukan peneliti pada tahap ini adalah sebagai berikut: 
a. Validasi ahli

Modul statistik pendidikan yang telah selesai disusun selanjutnya dilakukan validasi oleh pakar/ahli dalam bidang matematika dan pendidikan matematika. Dalam hal ini pakar/ahli adalah Bapak Yanuar Heri Murtianto, M.Pd dari Universitas PGRI Semarang, Bapak Heru Sukoco, S.Si, M.Pd dari Universitas Mercubuana Yogyakarta dan Ibu Nina Agustyaningrum, M.Pd dari Universitas Riau Kepulauan. Dari ketiga validator tersebut menyatakan bahwa modul layak digunakan dengan revisi. Adapun saran yang diperoleh dari ketiga validator tersebut adalah:

1. Ilustrasi kasus pada modul masih ada yang belum mengaplikasikan pendekatan kontekstual.

2. Beberapa konsep dasar perlu dikaji ulang misal istilah $F$ tuna cocok pada uji linieritas.

3. Terdapat beberapa konsep dasar yang harus diperbaiki.

4. Unsur interaktif dengan mahasiswa pada modul perlu ditambah.

5. Perlu ditambahkan uji asumsi klasik pada analisis regresi.

6. Contoh-contoh soal agar dibuat lebih variatif dan tidak monoton.

7. Tata-letak judul, sub judul termasuk penulisan bagian contoh dan latihan agar dibuat lebih unik untuk menandai urut-urutan materi.

8. Terdapat tata tulis yang harus diperbaiki.

Setelah dilakukan perbaikan kemudian modul dikembalikan kepada validator untuk dicek kembali. Berdasarkan hasil revisi semua validator menyatakan modul statistik pendidikan yang dikembangkan dinyatakan valid dan layak untuk digunakan untuk ujicoba pengembangan. Secara keseluruhan hasil validasi dari 3 validator diperoleh persentase kevalidan modul sebesar 85,71\% dengan kategori sangat baik

Setelah modul yang dikembangkan dinyatakan valid selanjutnya dilakukan uji praktikalitas untuk memperoleh informasi tentang kepraktisan atau kemudahan modul untuk digunakan dalam proses pembelajaran dengan menggunakan angket respon mahasiswa. Data hasil angket inilah yang digunakan untuk melihat kepraktisan modul. Hasil perolehan skor angket respon mahasiswa disajikan pada tabel 1 di bawah ini.

Tabel 1. Deskripsi data hasil angket respon mahasiswa

\begin{tabular}{lccccccc}
\hline & N & Min & Max & Sum & Mean & $\begin{array}{c}\text { Std. } \\
\text { Deviation }\end{array}$ & Variance \\
\hline $\begin{array}{l}\text { Respon } \\
\text { Mahasiswa }\end{array}$ & 22 & 36 & 49 & 925 & 42.05 & 3.316 & 10.998 \\
$\begin{array}{l}\text { Valid N } \\
\text { (listwise) }\end{array}$ & 22 & & & & & & \\
\hline
\end{tabular}

Berdasarkan tabel 1 di atas diperoleh skor maksimum sebesar 49, skor minimum sebesar 36, rata-rata sebesar 42,05. Berdasarkan kriteria kepraktisan modul termasuk kategori baik. Selanjutnya untuk melihat persentase pencapain kepraktisan modul dapat 
dihitung $\frac{42,05}{52} \times 100 \%=81,73 \%$. Berdasarkan hasil ini dapat ditarik kesimpulan bahwa modul praktis dan mudah untuk digunakan. Mahasiswa mengatakan bahwa modul mudah digunakan dan dapat membantu dalam memahami materi statistik pendidikan, bahasa yang digunakan dalam modul mudah dimengerti. Selama proses pembelajaran mahasiswa sangat antusias, hal ini terlihat pada saat mereka berdiskusi dengan temannya untuk menyelesaiakan permasalahan yang ada pada modul. Mahasiswa merasa sangat terbantu dalam mempelajari materi statistik pendidikan dengan modul, sehingga mereka bersemangat dalam perkuliahan. Selain itu juga mahasiswa dapat belajar secara mandiri di rumah.

Untuk mengukur keefektifan modul yang dikembangkan digunakan tes hasil belajar. Deskripsi data hasil tes yang diperoleh disajikan dalam tabel 2 berikut.

Tabel 2. Deskripsi data skor hasil tes statistik pendidikan

\begin{tabular}{|c|c|c|c|c|}
\hline & & & Statistik & Std. Error \\
\hline Hasil & Mean & & 81.250 & 2.8431 \\
\hline \multirow[t]{8}{*}{ Belajar } & 95\% Confidence & Lower Bound & 75.338 & \\
\hline & Interval for Mean & Upper Bound & 87.162 & \\
\hline & Median & & 82.500 & \\
\hline & Variance & & 177.827 & \\
\hline & Std. Deviation & & 13.3352 & \\
\hline & Minimum & & 55.0 & \\
\hline & Maximum & & 100.0 & \\
\hline & Range & & 45.0 & \\
\hline
\end{tabular}

Berdasarkan tabel 2 di atas terlihat bahwa rata-rata skor hasil tes sebesar 81,25 dengan simpangan baku sebesar 13,33. Selain itu dari deskripsi data tersebut kita peroleh skor maksimum sebesar 100 dan skor minimum sebesar 55 dengan sebaran data disajikan dalam histogram sebagai berikut.

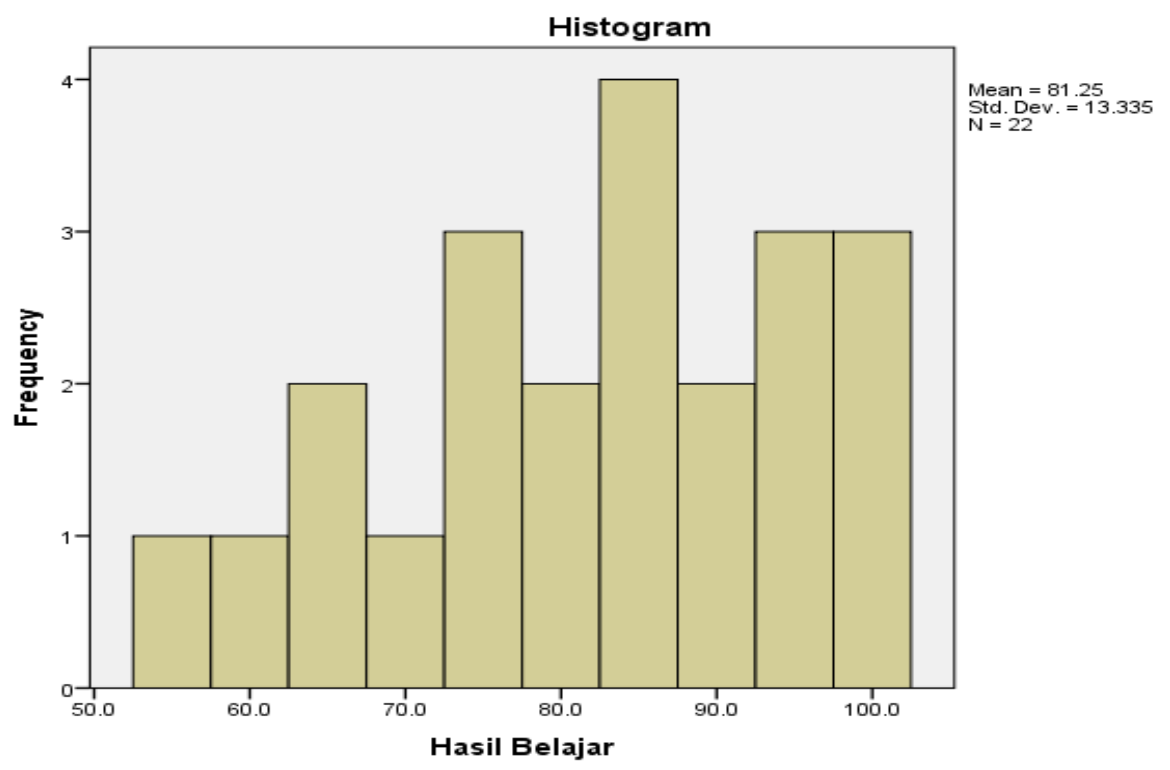

Gambar 1. Histogram Hasil Belajar Mahasiswa 
Selanjutnya data hasil tes mahasiswa akan dianalisis menggunakan uji t satu sampel dan uji klasikal. Sebelum dilakukan analisis menggunakan uji t satu sampel dilakukan uji normalitas data. Adapun hasil uji normalitas data dan hasil anlisis uji t satu sampel disajikan dalam tabel 14 dan 15 berikut.

Tabel 14. Tabel Normalitas

\begin{tabular}{lcccccc}
\hline & \multicolumn{3}{c}{ Kolmogorov-Smirnov $^{\text {a }}$} & \multicolumn{3}{c}{ Shapiro-Wilk } \\
& Statistik & Df & Sig. & Statistik & Df & Sig. \\
Hasil & .083 & 22 & $.200^{*}$ & .959 & 22 & .476 \\
Belajar & & & & & & \\
\hline
\end{tabular}

Berdasarkan hasil tersebut diperoleh nilai sig sebesar 0,200>0,05 sehingga dapat disimpulkan data berdistribusi normal.

Tabel 15. Hasil analisis uji one sample t test

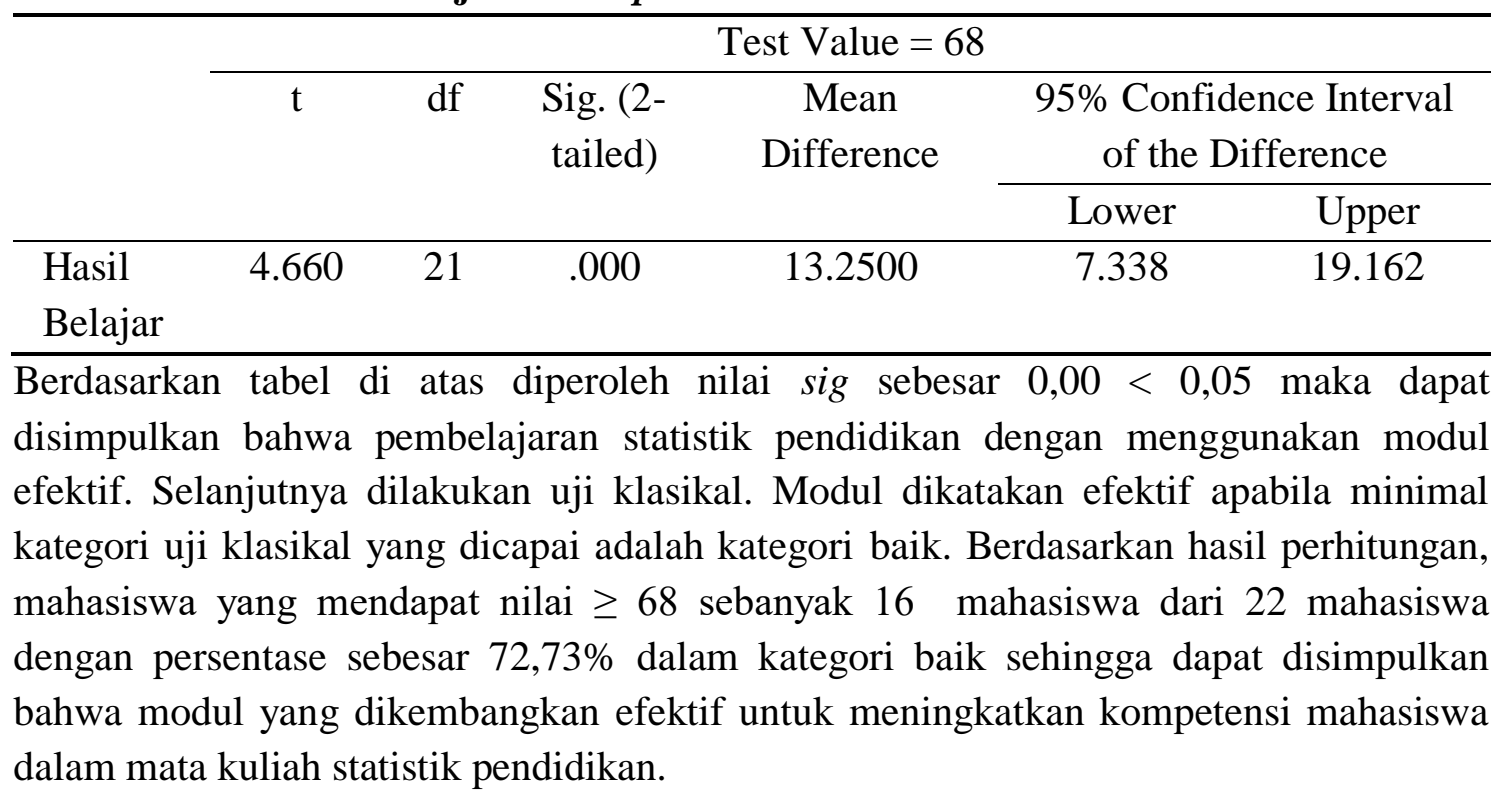

\section{Tahap Dissemination}

Tahap dissemination dalam penelitian ini dilakukan apabila modul dinyatakan valid, praktis dan efektif. Pada tahap ini modul yang dikembangkan tidak disebarluaskan secara luas melainkan hanya disebarluaskan untuk mahasiswa Universitas Riau Kepulauan Batam.

\section{Pembahasan}

Pada tahap pendefinisian (Define), dilakukan analisis ujung depan, analisis mahasiswa, analisis materi dan perumusan tujuan pembelajaran. Dari hasil analisis tersebut diperoleh permasalahan dalam pembelajaran statistik pendidikan dan kebutuhan mahasiswa terhadap bahan ajar mata kuliah statistik pendidikan. Sebagian besar mahasiswa menginginkan dikembangkan suatu bahan ajar yang dapat membantu mereka belajar secara mandiri. Sebanyak $17(80,95)$ mahasiswa menginginkan bahan ajar yang dikembangkan adalah berupa 
modul dan sisanya $(19,05 \%) 4$ mahasiswa menginginkan buku cetak. Selain itu beberapa mahasiswa juga mengatakan bahwa mereka memilih modul sebagai sumber belajarnya adalah karena dalam modul bahasanya lebih mudah dipahami dan disertai dengan contoh sehingga dapat memudahkan mereka untuk belajar. Sehingga peneliti dapat mendefinisikan bahan ajar yang akan dikembangkan adalah berupa modul.

Pada tahap perancangan (Design), dilakukan pemilihan media, pemilihan format, dan rancangan awal serta beberapa kegiatan yaitu menentukan media berdasarkan hasil tahap pendefinisian maka mengembangkan bahan ajar berupa modul, pengumpulan referensi yang dibutuhkan untuk mendukung penyusunan modul, membuat peta konsep untuk acuan dalam mengembangkan isi dari keseluruhan modul dengan memperhatikan urutan, membuat kerangka modul meliputi sistematika penyusunan materi untuk memudahkan proses penyusunan modul, dan penyusunan instrumen evaluasi penilaian modul yang meliputi angket penilaian untuk ahli materi dan ahli media untuk mengukur kevalidan modul, tes hasil belajar untuk mengukur keefektifan modul, dan angket respon siswa untuk mengukur kepraktisan modul.

Pada tahap pengembangan (Development), dilakukan validitas ahli dan uji coba pengembangan. Secara keseluruhan hasil validasi dari 3 validator diperoleh persentase kevalidan modul sebesar $85,71 \%$ dengan kategori sangat baik sehingga modul dikatakan layak digunakan. Selanjutnya dilakukan revisi di beberapa bagian pada modul setelah dilakukan revisi maka modul diujicobakan pada pembelajaran statistik pendidikan. Uji coba dilakukan pada semester VI kelas B yang berjumlah 22 mahasiswa. Setelah pembelajaran menggunakan modul selesai, mahasiswa diberikan soal tes hasil belajar. Mahaiswa yang memperoleh nilai $\geq 68$ sebanyak 16 mahasiswa dengan persentase sebesar $72,73 \%$ dalam kategori baik. Berdasarkan hasil uji t satu sampel diperoleh nilai sig $(0,00<0,05)$ sehingga dapat disimpulkan bahwa modul yang dikembangkan efektif untuk meningkatkan kompetensi mahasiswa dalam mata kuliah statistik pendidikan.

Selanjutnya untuk mengetahui kepraktisan modul, mahasiswa diberikan lembar penilaian berupa angket respon mahasiswa. Diperoleh hasil pengisian angket respon mahasiswa yaitu skor rata-rata hasil respon mahasiswa sebesar 42,05 dalam kategori baik, sehingga modul dikatakan praktis digunakan dalam kegiatan pembelajaran. Selanjutnya berdasarkan wawancara dengan mahasiswa pembelajaran dengan menggunakan modul statistik pendidikan berbasis CTL membuat mahasiswa lebih aktif dan termotivasi dalam pembelajaran. Selain mempermudah proses pembelajaran, modul juga dapat dipelajari secara mandiri oleh mahasiswa dirumah.

Pada tahap penyebaran atau diseminasi (Dissemination), modul yang sudah dikembangkan disebarluaskan untuk mahasiswa Universitas Riau Kepulauan Batam. Dari uraian di atas, dapat disimpulkan modul yang dikembangkan memiliki kualitas baik karena memenuhi tiga aspek yaitu valid, praktis dan efektif.

\section{Kesimpulan dan Saran}

Berdasarkan hasil analisis data dapat disimpulkan bahan ajar berupa modul statistik pendidikan berbasis CTL yang dihasilkan telah valid, praktis dan efektif dengan tingkat kevalidan sebesar $85,71 \%$ dengan kategori sangat baik, tingkat kepraktisan sebesar 81,73\% 
dengan kategori baik dan persentase ketuntasan secara kalsikal sebesar 72,73\% dalam kategori baik sehingga dapat disimpulkan bahwa modul yang dikembangkan efektif.

Berdasarkan hasil penelitian, maka peneliti dapat menyampaikan beberapa saran sebagai berikut: Bahan ajar berupa modul statistik pendidikan berbasis CTL perlu disempurnakan kembali, jika memang hal tersebut bermanfaat dan menghasilkan produk yang lebih berkualitas. Bagi pembaca yang tertarik dengan penelitian ini dapat mengembangkan modul berbasis CTL pada materi pembelajaran yang berbeda atau pada mata kuliah yang lain.

\section{Daftar Pustaka}

Anwar, I. (2010). Pengembangan Bahan Ajar. Bahan Kuliah Online. Bandung: Direktori UPI.

Kahle. D. (2012). Animating Statistiks: A New Kind of Applet for Exploring Probability Distributions. Journal of Statistiks Education, 22(2).

Nasiroh, D. (2014). Pengembangan Modul dengan Pendekatan Kontekstual pada Materi Barisan dan Deret untuk Siswa SMP Terbuka Kelas IX. Universitas Negeri Yogyakarta.

Nasution. (2005). Berbagai Pendekatan Dalam Proses Belajar Mengajar. Jakarta: PT Bumi Aksara.

Régnier, Jean C. \& Kuznetsova, E. (2014). Teaching of Statistiks: Formation of Statistikal Reasoning. In Procedia social and behavioral sciences. Retrieved from http://ac.elscdn.com/S1877042814055694/1-s2.0-S1877042814055694-main.pdf?_tid=182a2b3c53b0-11e7-8a1b00000aacb35d\&acdnat=1497740324_3ebb06f72cddd24cff2b82b7999b075c

Shahidayanti, Tutik., Dhoruri, A. \& M. (2014). Pengembangan Modul pada Materi Segi Empat untuk Siswa Kelas VII SMP Berdasarkan Pendekatan Kontekstual untuk Meningkatkan Hasil Belajar Siswa. Universitas Negeri Yogyakarta.

Thiagarajan, S., Semmel, D. S \& Semmel, M. I. (1974). Instructional Development for Training Teachers of Expectional Children. Minnesota: Leadership Training Institute/Special Education, University of Minnesota. 